\title{
The Mediating Effect of Symptoms of Anxiety on the Relationship between Appraisal and Teaching Competence
}

\author{
Gilly B. Ferrando \\ University of Mindanao Professional Schools, Philippines \\ e-mail: gilly.ferrando@deped.gov.ph \\ Jerlyn G. Balones \\ University of Mindanao Professional Schools, Philippines \\ e-mail: jerlyn_balones@umindanao.edu.ph \\ Article History: Received on 13 November 2021, Revised on 20 November 2021 \\ Published on 21 November 2021
}

\begin{abstract}
This study determined the mediating effect of symptoms of anxiety on the relationship between appraisal and teaching competence of teachers in San Isidro North and South Districts. The descriptive-correlational research design was utilized and employed stratified random sampling with 300 teachers as sample. Data collection was made through survey instruments. Data analysis was done through Mean, Pearson-r, Multiple Regression and Medgraph using Sobel z-test. Results revealed that symptoms of anxiety was high while appraisal and teaching competence were very high. A positive correlation between appraisal and teaching competence, appraisal and symptoms of anxiety, and symptoms of anxiety and teaching competence was proven in the study. The findings affirmed that symptoms of anxiety played a partial mediation thus, it cannot fully account on the influence of appraisal towards teaching competence. Moreover, a high level of symptoms of anxiety did not hinder teachers' capability to be very highly competent in teaching.
\end{abstract}

Keywords: Education, Appraisal, Teaching Competence, Symptoms of Anxiety, Mediation

\section{A. Introduction}

Teaching competence as a fundamental element in the educational system forms the basis of nation's educational status (Fachrurazzi, 2017). With this, competence and eligibility are required for teachers (Syamsinar \& Jabu, 2015). Over the past years, professionals, lawmakers and researchers continuously probe on the indications of teaching competence among teachers (Kim, Jörg \& Klassen, 2019). Queries are directed towards the evidence of teaching competence since credentials alone cannot guarantee that teachers possess the required competence in teaching (Soepriyatna, 2012).

While competent teachers foster an improved student performance, on the other hand, incompetent teachers hamper learners' instructional outcomes (Grauf, 2015). Students taught by incompetent teachers were unable to advance to another level compared to others (Hardin, 2019). Problems sprout since having poor teaching competence compromises learners' academic achievement (Sumaryanta, Mardapi, Sugiman \& Hirawan, 2018).

Teaching competence as a concept has been defined by various authors in diverse perspectives. For instance, teaching competence is the individual's capacity to perform tasks bearing the 
skills, cognition, and attitude as job requirements (Ludwikowska, 2019; Qodriyah, 2016; Soepriyatna, 2012 ) and is characterized as the teacher's ability to do the task at a certain level (Casolo, Coco, Frattini, Vago \& Casolo, 2019). While Thakur and Shekhawat (2014) defined competence as a way of imparting knowledge and skills to the learners, Amalia and Saraswati (2018) regarded teaching competence as a contributory element in developing teachers' job performance in the field of teaching. Teaching competence possessed by teachers is the most fundamental part of the educational system and forms the basis of the quality of education in a certain country (Fachrurrazi 2017).

Employing competent teachers and keeping them in current position is one of the most essential factors in promoting quality education and improving student achievement (Grauf, 2015). In fact, Hardin (2019) posited that students need competent teachers who will scaffold them to become better learners who continuously grow and develop.

A general notion posits that teachers' positive attributes influence the condition of educational outcomes (Beckmann, 2018). An advanced teaching competence transmits an outstanding level of education, while poor teaching competence presupposes a poor educational status (Fachrurrazi, 2017). Teaching competence caters the scholastic attainment of learners and enhances students' abilities which serves as basis of the enhancement of teacher practices (Omar, Hassan, Ahmad \& Roslan, 2018). Thus, in order for students to compete on different areas in the global setting, it is deemed necessary to address academic disparities and improve teachers' competence (Hardin, 2019).

Albert Bandura's self-efficacy theory explains the relationship between appraisal and teacher competence which states that self-efficacy beliefs influence teachers' motivation on the appraisal process, which in turn develops teaching effectiveness and competence (Becchio, 2016). Congruently, the self-determination theory of Edward Deci and Richard Ryan also explains that teachers' attitude and motivation towards performance appraisal will significantly predict the outcomes and teacher's level of competence and performance (Deci \& Ryan, 2008). Meanwhile, the stimulus-response theory of B.F. Skinner establishes the connection between appraisal as the stimulus and symptoms of anxiety as response (Nazir, 2018). As revealed by Larsen (2009), some teachers regard appraisal as the root of stress, apprehension and anxiousness. Lastly, the Psychoanalytic Theory of Sigmund Freud proposes that anxiety hinders individuals to do tasks and impedes willingness to attain desired targets (Akman, Izgi, Bağçe \& Akilli, 2007), thus affecting the quality of teachers (Aslrasouli \& Vahid, 2014). Given that teaching is an anxiety-provoking job, symptoms of anxiety could affect the extent of teachers' competence and effectiveness.

Since most of the existing literatures mainly focused on teacher evaluation process, teacher's role in the classroom and teaching competence framework, more studies are required to support the claims on the effect of teacher appraisal and teaching competence on the educational system. After reading several researches, none has dealt with the analysis on how symptoms of anxiety mediates the relationship between appraisal and teaching competence among public school teachers.

There is a need to conduct this study in the locale to guide administrators in formulating strategic plans on how to improve the competence of teachers in San Isidro North and South Districts since students' poor academic performance were attributed to the incompetence of 
teachers. In addition, this study seeks to probe the mediating role of symptoms of anxiety and its influence on the relationship between appraisal and teaching competence of teachers.

The main purpose of this study was to find out the mediating effect of symptoms of anxiety on the relationship between appraisal and teaching competence of teachers. Specifically, this study: 1) Assessed the level of appraisal of teachers in terms of: professional development and performance; teaching and learning; and pupils' learning experiences and progress. 2) Ascertained the level of teaching competence of teachers in terms of: planning; development; and result. 3) Evaluated the level of symptoms of anxiety of teachers. 4) Determined the significant relationship between: appraisal and teaching competence; appraisal and symptoms of anxiety; and symptoms of anxiety and teaching competence. 5) Found out the significant mediating effect of symptoms of anxiety on the relationship between appraisal and teaching competence of teachers.

\section{B. Methods}

This study was conducted in 14 elementary and 3 secondary schools in San Isidro North and San Isidro South Districts in the Municipality of San Isidro, Davao Oriental. This is a third class municipality and is one of the gulf-towns of Davao Oriental. This research was conducted at approximately 10 months starting from December 2020 to October 2021.

This study utilized a quantitative, non-experimental research design particularly descriptivecorrelational technique. In a broader sense, quantitative research is used to quantify the existence of relationships between and among variables under investigation (Sousa et al. 2002). A non-experimental research design is used to discover, distinguish and analyze connections between and among the variables without the researcher's intervention, variable manipulation or comparison between groups (Sousa, Driessnak \& Mendes, 2002; Glasofer \& Townsend, 2020).

Moreover, a descriptive-correlational technique was specifically used to describe the variables and the correlations that happen naturally (Sousa, Driessnak \& Mendes, 2002). This technique had sought to determine whether changes in a certain variable relates to the changes that occur with the other variable (de Lima \& Valério 2011; Sousa, Driessnak \& Mendes, 2002). Furthermore, mediation was also employed in this study. MacKinnon (2007) pointed out that mediation is a presupposed causative sequence in which the independent variable causes the mediating variable, which in turn, causes the dependent variable.

This study utilized an adapted survey questionnaire administered to three secondary schools and 14 elementary schools in both districts. The instrument was validated by five experts from the University of Mindanao Professional Schools. From the total population, a sample of 300 teachers were taken as study informants. Regular and permanent public elementary and secondary school teachers who were currently teaching were the respondents of the study. To get the sample size, the researchers utilized a stratified random sampling. Respondents were drawn from each subgroup to suffice the data needed for the study. The sample obtained was disproportionate due to low number of teachers in some small-sized schools. Data collection was made through the use of adapted survey instrument. Analysis of data was done with the use of Mean, Pearson Product Moment Correlation Coefficient, Multiple Regression Analysis and Medgraph using Sobel z-test. 
Volume 2 (2) 2021

E-ISSN: 2723-6919 P-ISSN: 2746-0827

\section{Results and Discussion}

In Table 1 below, the level of appraisal among public elementary and secondary school teachers of San Isidro North and South Districts has a weighted mean of 4.40 with a standard deviation of .375 and a verbal interpretation of very high. The results show that teaching and learning has the highest mean value of 4.54 which is described as very high. Meanwhile, professional development and performance has the lowest mean value of 4.12 which is described as high. Since 4.40 falls within the range of 4.20-5.00, this means that appraisal is always observed by teachers.

Table 1. Appraisal among Public Elementary and Secondary School Teachers of San Isidro North and San Isidro South

\begin{tabular}{cccc}
\hline Indicators & Mean & SD & Descriptive Level \\
\hline Professional Development and Performance & 4.12 & .458 & high \\
Teaching and Learning & 4.54 & .405 & very high \\
Pupils' Learning Experiences and Progress & 4.45 & .445 & very high \\
Overall & 4.40 & .375 & very high \\
\hline
\end{tabular}

In Table 2 below, the level of teaching competence among public elementary and secondary school teachers of San Isidro North and South Districts has an overall weighted mean of 4.42 with a standard deviation of .418 described as very high. The results revealed that development has the highest mean value of 4.50 with a standard deviation of .385 bearing a descriptive interpretation of very high. Correspondingly, planning has the lowest mean value of 4.35 and a standard deviation of .528, having the descriptive interpretation of very high. All of the indicators got a mean score ranging from 4.35-4.50. This means that teaching competence is always manifested by teachers.

Table 2. Teaching Competence among Public Elementary and Secondary School Teachers of San Isidro North and San Isidro South

\begin{tabular}{cccc}
\hline Indicators & Mean & SD & Descriptive Level \\
\hline Planning & 4.35 & .528 & very high \\
Development & 4.50 & .385 & very high \\
Results & 4.41 & .497 & very high \\
Overall & 4.42 & .418 & very high \\
\hline
\end{tabular}

Revealed in Table 3 below is the level of symptoms of anxiety among public elementary and secondary school teachers of San Isidro North and South Districts with an overall weighted mean score of 3.96 and a standard deviation of .449 with a descriptive interpretation of high. The mean score of the items range from 2.81-4.74 which means that out of the 15 responses, two are moderate, 8 items are high and five items are very high. However, the overall mean 
Volume 2 (2) 2021

E-ISSN: 2723-6919 P-ISSN: 2746-0827

score of 3.96 falls with the range of $3.40-4.19$, which means that symptoms of anxiety is oftentimes manifested by teachers.

Table 3. Symptoms of Anxiety among Public Elementary and Secondary School Teachers of San Isidro North and San Isidro South

Indicators $\quad$ Mean $\quad$ SD $\begin{gathered}\text { Descriptive } \\ \text { Level }\end{gathered}$

1. Being a dedicated teacher.

2. Realizing ambitions.

3. Being an enthusiast and optimist as to profession.

4. Being self-confident and a successful person.

5. Liking public speeches and feeling comfortable when being looked by others.

$\begin{array}{ccc}4.74 & .481 & \text { very high } \\ 4.58 & .587 & \text { very high } \\ 4.56 & .600 & \text { very high } \\ 4.17 & .749 & \text { high } \\ 3.47 & .919 & \text { high } \\ 3.67 & .822 & \text { high } \\ 3.56 & .759 & \text { high } \\ 4.25 & .666 & \text { very high } \\ 2.81 & 1.022 & \text { moderate } \\ 3.64 & .980 & \text { high } \\ 3.90 & .881 & \text { high } \\ 3.37 & 1.069 & \text { moderate } \\ 4.19 & .918 & \text { high } \\ 4.52 & .652 & \text { very high } \\ 3.98 & .856 & \text { high } \\ 3.96 & .449 & \text { high }\end{array}$

Revealed in Table 4 below are the results of the test of relationship between appraisal and teaching competence, appraisal and symptoms of anxiety, and symptoms of anxiety and teaching competence. The relationship is significant if the p-value is less than 0.05. Meanwhile, a p-value which is more that 0.05 means that the relationship is not significant. Reflected on the table below, appraisal and teaching competence has an r-value of 0.751 and a p-value of 0.000. This means that there is a significant relationship between appraisal and teaching competence. Appraisal is correlated with teaching competence signifying a positive correlation, thus, rejecting the null hypothesis.

In addition, exhibited in Table 4 below is the result of the test of relationship between appraisal and symptoms of anxiety. The result reveals that teacher appraisal is positively correlated with symptoms of anxiety with an r-value of .533 and p-value of 0.000 . This means that teacher 
Volume 2 (2) 2021

E-ISSN: 2723-6919 P-ISSN: 2746-0827

appraisal is positively correlated with symptoms of anxiety, hence, rejecting the null hypothesis. Lastly, the results of the test of relationship between symptoms of anxiety and teaching competence can also be seen in Table 4 below. It is shown that symptoms of anxiety has a positive correlation with teaching competence with an r-value of 0.513 and $p$-value of 0.000 This means that symptoms of anxiety is positively correlated with teaching competence, thus, the null hypothesis stating no significant relationship is rejected.

Table 4. Correlation Analysis of the Variables

\begin{tabular}{ccccc}
\hline Pair & Variables & $\begin{array}{c}\text { Correlation } \\
\text { Coefficient }\end{array}$ & p-value & $\begin{array}{c}\text { Decision } \\
\text { on Ho }\end{array}$ \\
\hline IV and DV & $\begin{array}{c}\text { Appraisal and Teaching } \\
\text { Competence }\end{array}$ & 0.751 & 0.000 & Reject \\
IV and MV & $\begin{array}{c}\text { Appraisal and Symptoms of } \\
\text { Anxiety }\end{array}$ & 0.533 & 0.000 & Reject \\
MV and DV & $\begin{array}{c}\text { Symptoms of Anxiety and } \\
\text { Teaching Competence }\end{array}$ & 0.513 & 0.000 & Reject \\
\hline
\end{tabular}

Displayed in Table 5 below is the regression analysis on the mediating effect of symptoms of anxiety on teacher appraisal and teaching competence. The data in this table were utilized as input to the medgraph. In Step 1 (Path c), teacher appraisal as the independent variable (IV) significantly predicts teaching competence, the dependent variable (DV). In Step 2 (Path a), teacher appraisal (IV) significantly predicts the symptoms of anxiety, the mediating variable (MV). In Step 3 (Path b), symptoms of anxiety (MV) significantly predicts teaching competence (DV). In Step 4, the combined effect of teacher appraisal and symptoms of anxiety on teaching competence is significant.

The researchers affirmed that mediation is significant and there is partial mediation. First regression, the independent variable (teacher appraisal) affects the dependent variable (teaching competence) at beta coefficient of 0.836 with p-value of less than 0.05 and the relationship is significant. Second regression, the independent variable (teacher appraisal) affects the mediating variable (symptoms of anxiety) at beta coefficient of 0.638 with a p-value of less than 0.05 and the relationship is significant. Third regression, the mediating variable (symptoms of anxiety) affects the dependent variable (teaching competence) at beta coefficient of 0.146 with a p-value of less than 0.05 and the relationship is significant. Finally, the dependent variable (teaching competence) is regressed on both the independent variable (teacher appraisal) and the mediator (symptoms of anxiety). Since the coefficient of the teacher appraisal has been reduced from 0.836 to 0.743 , but still significant, partial mediation of symptoms of anxiety on the relationship between teacher appraisal and teaching competence is achieved. 
Volume 2 (2) 2021

E-ISSN: 2723-6919 P-ISSN: 2746-0827

Table 5. Regression Results of the Variables in the Four Criteria of the Presence of Mediating Effect

\begin{tabular}{ccccc}
\hline Step & Path & $\begin{array}{c}\text { Beta } \\
\text { (Unstandardized) }\end{array}$ & $\begin{array}{c}\text { Standard } \\
\text { Error }\end{array}$ & $\begin{array}{c}\text { Beta } \\
\text { (Standardized) }\end{array}$ \\
\hline Step 1 & c & 0.836 & 0.043 & 0.751 \\
Step 2 & a & 0.638 & 0.059 & 0.533 \\
Step 3 & b & 0.146 & 0.041 & 0.157 \\
Step 4 & c & 0.743 & 0.049 & 0.668 \\
\hline
\end{tabular}

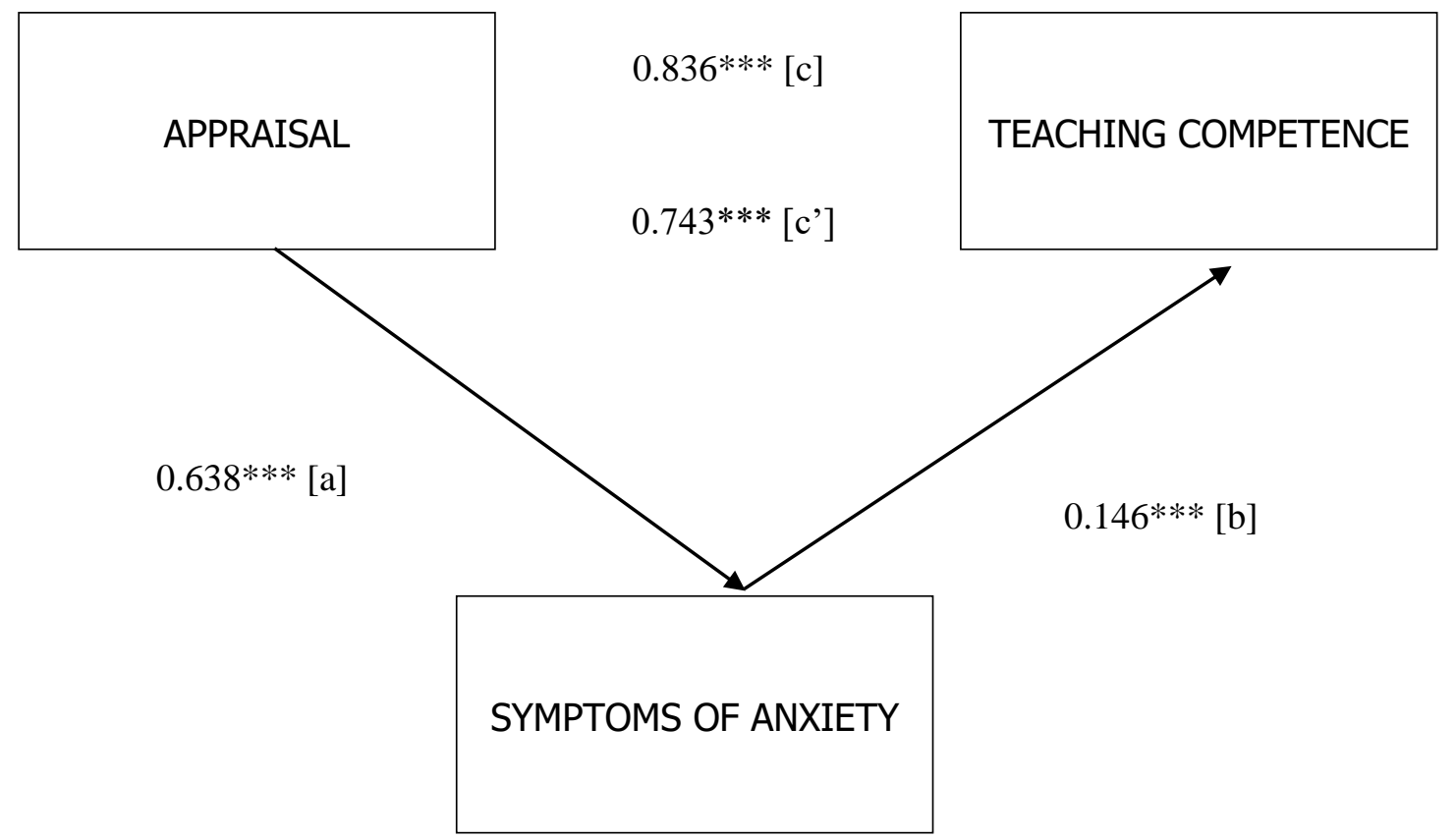

Figure 1. Medgraph Showing the Variables of the Study

\section{Mediation Analysis}

Sobel z-value 3.366487, $p<0.05$ Percentage of the total effect that is mediated $11.146463 \%$ Ratio of the indirect to the direct effect 0.125448

Effect Size Measures

Unstandardized Coefficients

Total $\quad: .836$

Direct $\quad: .743$

Indirect $\quad: .146$

Ratio Index $\quad: .175$

To assess the significance of the mediating effect, the use of medgraph which involves Sobel z-test was utilized for further mediation. Full mediation will be attained if the effect of the IV on DV is not significant at the last step in the analysis. With this, all of the effects are mediated by the mediating variable. Partial mediation will be achieved if the regression coefficient is reduced but remains significant in the last step. Part of the IV is mediated by the MV but other 
Volume 2 (2) 2021

E-ISSN: 2723-6919 P-ISSN: 2746-0827

parts are either direct or mediated by other variables which are not included in the model. In this case, the effect of teacher appraisal (IV) on teaching competence (DV) is weakened as revealed in the lowered beta value after symptoms of anxiety (MV), thus, showing a significant relationship that implies a partial mediation.

As shown in the Mediation Analysis above, the Sobel z-value of 3.366487 yielded a p-value which is less than 0.05 , thus significant partial mediation occurred. The association between teacher appraisal (IV) and teaching competence (DV) has been significantly reduced through the inclusion of the mediating variable which is symptoms of anxiety. It is visible in the graph that 0.836 is significantly reduced to 0.743 in the succeeding regression. The effect size which is .175 measures how much of the effect of teacher appraisal (IV) on teaching competence (DV) can be attributed to the indirect path (IV to MV to DV). The total effect (.836) is the raw correlation between teacher appraisal (IV) and teaching competence (DV). The direct effect (.743) is the size of the correlation between teacher appraisal (IV) and teaching competence (DV) with the inclusion of symptoms of anxiety (MV) in the regression. The indirect effect which is .146 is the original correlation between the IV and the DV that undergoes through the MV to the DV. In terms of the ratio index, it seems that about $17.5 \%$ of the total effect of the IV on the DV goes through the MV, and about $82.5 \%$ of the total effect is either direct or mediated by other variables not included in the model.

Based on the findings, the very high level of teacher appraisal is in congruence with the perspectives of Kagema and Irungu (2018) which states that performance appraisal should be at the highest level for the purpose of achieving the goals of the educational institutions. With this, teacher appraisal must support teachers' professional growth and career advancement (Zhang \& Ng, 2011; Curran, 2014). Specifically, the high level of professional development and performance conforms to the views of Monyatsi, Steyn and Kamper (2006) ) and Curran (2014) which state that appraisal practices are significant in honing teachers' professional self within their teaching career. Thus, leading to the enhancement of teaching performance (Hakrim, 2015). With this, the use of teacher appraisal system has made teachers more accountable of their teaching practices (Rigsby, 2014; OECD, 2013; Matete, 2016).

Further, the very high level of pupil's learning experiences and progress is aligned with the viewpoints of Cotton (1998) which posits that tracking and assessing students' learning is a key ingredient of a quality education. In terms of the overall descriptive level, this study is higher compared to the results of the study of Monyatsi, Steyn and Kamper (2006) which revealed that teacher appraisal system in Botswana is satisfactory. While the result on the level of teacher appraisal in the present study is very high, Odhiambo (2005), on the other hand, reported the weakness of the teacher appraisal practices in secondary schools in Kenya which must be immediately addressed if used for enhancing educational quality. Meanwhile, Flores (2012) also made mention about the uncertainty and skepticism of teachers' perception on teacher appraisal in Portugal.

The very high level of teaching competence conformed to the findings of Vecaldo, Andres, Carag and Caraguian (2017) which indicated that elementary school teachers are very competent in terms of pedagogical competence using the imposed standards for professional teachers. In addition, they also exhibit exceptional performance in academics. Meanwhile, the present study is partly similar with the study of Murkatik, Harapan and Wardiah (2020) which revealed that professional and pedagogical competence have partially influenced the performance of teachers. 
The current result of the level of teaching competence is higher compared to the findings of Achwarin (2009) as results have shown that the level of teaching competence among teachers of the Thailand was documented as high. The findings of the previous study is lower compared to the result of the present study. While the results on the recent study reveals a very high level of competence among teachers, Beckmann (2018), however, discovered that the quality of learners in South Africa was below average due to the fact that considerable number of teachers were not competent.

The high level of symptoms of anxiety conformed to the study of Aslrasouli and Vahid (2014) in Iran where teachers bear a high level of anxiety for both experienced and novice teachers. In fact, a high level of anxiousness was felt by teachers across all genders. Subsequently, the present study is aligned with the study of Othman and Sivasubramaniam (2019) which showed that a high prevalence of depression, stress and anxiety were reported among Malaysian secondary school teachers. This, in turn, affirms that teaching is indeed a highly-stressful career to undertake. Similarly, this study is congruent with the findings of Desouky and Allam (2017) which revealed that occupational stress, anxiety and depression were experienced by Egyptian teachers, and that anxiety and depression have surged higher over the course of the year among teachers of Ghana (Peele \& Wolf, 2020).

The result on the relationship between appraisal and teaching competence showed a significant relationship. This means that teacher appraisal is correlated with teaching competence. This result is aligned with the study of Zhang and $\mathrm{Ng}$ (2011) as revealed in the study that teacher appraisal system was able to positively uplift the Chinese teachers' professional competence and development at some point. Hence, teacher appraisal must support teachers' professional growth and career advancement (Zhang \& Ng, 2011; Curran, 2011).

Further, the significant relationship between appraisal and teaching competence is in congruence with the views of Elliott (102) which highlights that an effective teacher appraisal should settle between performance assessment and personal improvement assistance. Thus, teacher appraisal has a positive influence towards teaching performance and effectiveness (Elliot, 2015; Becchio, 2016).

The test of relationship between appraisal and symptoms of anxiety revealed a positive significant relationship. Unpredictably, the result showed a positive correlation wherein teacher appraisal has a significant effect on symptoms of anxiety. This study is similar with the findings of Brady (2016) which revealed that teacher appraisal has evoked anxiety among teachers. As teacher appraisal arouses anxiety among teachers, self-evaluation has been the focus of some appraisers to give teachers the opportunity of balancing teacher's volition and responsibility. Further, the results of this study is similar with Larsen (2009) which revealed that some teachers claimed that appraisal had a positive effect on enhancing their capabilities in the field. However, most of them had expressed that teacher appraisal had caused them stress, selfapprehension and anxiousness.

The test of relationship between symptoms of anxiety and teaching competence showed a positive significant relationship. The result on the test of relationship between symptoms of anxiety and teaching competence is aligned with the viewpoints of Gaesser (2018) which states that a high level of anxiety can be a good reference of motivation for a person to be at his or her best. This, in turn fuels the teacher to do better in his or her job (Koçak \& Seçer, 2018). 
The mediation analysis showed that symptoms of anxiety partially mediate the relationship between teacher appraisal and teaching competence. Since it is only partial mediation, it cannot entirely claim that symptoms of anxiety is the sole reason how teacher appraisal affects teaching competence among public schools teachers of San Isidro North and South Districts. This means that symptoms of anxiety can be one of the many reasons how teacher appraisal can influence teaching competence.

\section{Conclusion}

The findings of the study affirmed the mediating effect of symptoms of anxiety on the relationship between teacher appraisal and teaching competence. Even if the symptoms of anxiety played a partial mediation, it cannot fully account on the influence of teacher appraisal towards teaching competence. The findings showed that teacher appraisal is significant in teaching competence. Teachers manifested a very high level of teacher appraisal, high level of symptoms of anxiety and a very high level of teaching competence. We can conclude that there is a significant relationship between teacher appraisal and teaching competence, teacher appraisal and symptoms of anxiety, and symptoms of anxiety and teaching competence. Although teachers have manifested a high level of symptoms of anxiety, still, they showed a very high level of teaching competence and a very high level of teacher appraisal. This means that symptoms of anxiety does not hinder the capacity of teachers to become very highly competent in the field.

\section{E. Acknowledgement}

We thank to Rector University of Mindanao Professional Schools, Philippines and friends who have supported us to do this project.

\section{References}

Achwarin, N. (2009). The study of teacher competence of teachers at schools in the three southern provinces of Thailand." Scholar, 1(1).

Akman, B., Izgi, Ü., Bağçe, H. \& Akilli, H. A. (2007). The effect of elementary students' attitude towards science on their levels of test anxiety." Education and Science, 32(146), 3-11.

Amalia, L. \& Saraswati, T. (2018). The impact of competencies toward teacher's performance moderated by the certification in Indonesia." KnE Social Sciences, 86-98.

Aslrasouli, M. \& Vahid, M.S.P. (2014). An investigation of teaching anxiety among novice and experienced Iranian efl teachers across gender. Social and Behavioral Sciences, 98, 304-313.

Becchio, J.A. (2016). Teacher evaluation and its impact on teacher self-efficacy".

Beckmann, J.L. (2018). Competent educators in every class: the law and provision of educators. Journal for Juridical Science, 43(2), 1-31. 
Brady, A. (2016). The regime of self-evaluation: self-conception for teachers and schools. British Journal of Education Studies, 1-18.

Casolo, F., Coco, D., Frattini, G. \& Casolo, A. (2019). Effective teaching competences in physical education. Journal of Physical Education and Sport, 19(5), 1806-1813.

Cotton, K. (2004). Monitoring student learning in the classroom. School Improvement Research Series, 1998, 1-15.

Curran, C. (2011). In-service teacher perception of feedback from formative evaluation within the teacher appraisal process and its relationship to teacher self-efficacy. (Doctoral Dissertation) Retrieved from search.proquest.com/docview/1719539263/519FFBA76B994B1DPQ/1?accountid=31 259.

Deci, E. \& Ryan, R. (2008). Self-determination theory: a macrotheory of human motivation, development, and health. Canadian, Psychological Association, 49(3), 182-185.

De Lima, M. \& Valerio, D. (2011). Research design: A contribution to the author. Online Brazilian Journal of Nursing, 10(2), 1-18.

Desouky, D. \& Allam, H. (2017). Occupational stress, anxiety and depression among Egyptian teachers. Journal of Epidemiology and Global Health, 7, 191-198.

Elliot, K. (2015). Teacher performance appraisal: more about performance or development? Australian Journal of Teacher Education, 40(9), 102-116.

Fachrurrazi, (2017). Relationship between teacher professional competences and teacher work-autonomy. (Doctoral Dissertation) Retrieved from www.semanticscholar.org/paper/Relationship-between-Teacher-ProfessionalandFachrurrazi/3569442a43fc6ce3ed495340915396482084fd81.

Flores, M.A. (2012). The implementation of a new policy on teacher appraisal in Portugal: How do teachers experience it at school? Educ Asse Eval Acc, 24, 351-368.

Gaesser, A. (2018). Befriending anxiety to reach potential strategies to empower our gifted youth." Gifted Child Today, 41(4), 186-195.

Glasofer, A. \& Townsend, A. (2020). Determining the level of evidence: nonexperimental research designs." Nursing Critical Care, 15(1), 24-27.

Grauf, C. (2015). Principals' perceptions of incompetent teachers: incidence rates, characteristics, and barriers to dismissal in Missouri. (Doctoral Dissertation) Retrieved from www.proquest.com/docview/1678954550/FB3E8C5D85344CDFPQ/1?accountid=31 259.

Hakrim, B.M. (2015) Teacher evaluation as a tool for professional development: A case of Saudi Arabia. Advances in Language and Literary Studies, 6(5), 97-103. 
Hardin, J. (2019). Principal stories of working with ineffective teachers. (Doctoral Dissertation) Retrieved from www.proquest.com/docview/2287611651/6424099E214F46D2PQ/1 ?accountid=3125 9.

Kagema, J. \& Irungu, C. (2018). An analysis of teacher performance appraisals and their influence on teacher performance in secondary schools in Kenya. International Journal of Education, 11(1), 93-98.

Kim, L., Jörg, K. \& Klassen, R. (2019). A meta-analysis of the effects of teacher personality on teacher effectiveness and burnout. Educational Psychological Review, 31, 163-195.

Kocak, L. \& SeÇer, I. (2018). Investigation of the relationship between school burnout, depression and anxiety among high school students. Çukurova Üniversitesi Ë̆itim Fakültesi Dergisi, 47(2), 601-622.

Larsen, M. (2009). Stressful, hectic, daunting: A critical policy study of the Ontario teacher performance appraisal system. Canadian Journal of Education al Administration and Policy, (95), 1-44.

Ludwikowska, K. (2019). Teacher Competence inventory an empirical study on futureoriented competences of the teaching profession in higher education in India. Education + Training, 61(9), 1123-1137.

MacKinnon, D., Fairchild, A. \& Fritz, M. (2007). Mediation analysis. Annu Rev Psychol, 58(593), 1-22.

Matete, R.E. (2016). Implementation of management by objective through open performance review and appraisal system for teachers in Tanzania. International Journal of Education \& Literacy Studies, 4(3), 24-33.

Monyatsi, P., Steyn, T. \& Kamper, G. (2006). Teacher perceptions of the effectiveness of teacher appraisal in Botswana.” South African Journal of Education, 26(3), 427-441.

Murkatik, K., Harapan, E. \& Wardiah, D. (2020). The influence of professional and pedagogic competence on teacher's performance. Journal of Social Work and Science Education, $1(1), 58-69$.

Nazir, F. (2018). Stimulus response theory: a case study in the teaching and learning of Malay language among year 1 pupils. The Journal of Social Sciences Research, 4(10), 153157

Odhiambo, G. (2005). Teacher appraisal: the experiences of Kenyan secondary school teachers. Journal of Educational Administration, 43(4), 402-416.

OECD (2013). Teacher appraisal: Enhancing teacher professionalism in synergies for better learning: An international perspective on evaluation and assessment, OECD Publishing, Paris, DOI: https://doi.org/10.1787/9789264190658-9-en 
Othman, Z. \& Sivasubramaniam, V. (2019). Depression, anxiety, and stress among secondary school teachers in Klang, Malaysia. International Medical Journal, 26(2), 71-74.

Omar, R., Hassan, S., Ahmad, N.A. \& Roslan, S. (2018). Importance of teachers' competency through students' perception in relationships between parental involvement and motivation with students' achievement. Sains Humanika, 10(3), 17-23.

Peele, M. \& Wolf, S. (2020). Predictors of anxiety and depressive symptoms among teachers in Ghana: Evidence from a randomized controlled trial. Social Science \& Medicine, 253, 1-10.

Qodriyah, W.R. (2016). An analysis of teachers' pedagogical competence in teaching English for young learners at nara islamic school cirebon. Doctoral Dissertation. Retrieved from core.ac.uk/download/pdf/147421096.pdf.

Rigsby, D. (2014). Teachers' perceptions regarding one district's newly implemented appraisal system. (Doctoral Dissertation) Retrieved from www.proquest.com/docview/1651196040/367B32187E34F3FPQ/1?accountid=31259.

Soepriyatna. (2012). Investigating and assessing competence of high school teachers of English in Indonesia. Malaysian Journal of ELT Research, 8(2), 38-49.

Sousa, V., Driessnak, M. \& Mendes, I. (2007). An overview of research designs relevant to nursing: Part 1: Quantitative research designs. Rev Latino-am Enfermagem, 15(3), 502507.

Sumaryanta, Mardapi, D., Sugiman \& Herawan, T. (2018). Assessing teacher competence and its follow-up to support professional development sustainability. Journal of Teacher Education for Sustainability, 20(1), 106-123

Syamsinar, H. \& Jabu, B. (2015). The problems in professional competence of teachers in teaching English subject at vocational high schools. ELT Worldwide, 2(2), 95-109

Thakur, A. \& Shekhawat, M. (2014). The study of different components of teacher competencies and their effectiveness on student performance. International Journal of Engineering Research \& Technology, 3(7), 1426-1428.

Vecaldo, R., Andres, A., Carag, C. \& Caraguian, C. (2017). Pedagogical competence and academic performance of pre-service elementary teachers in Tuguegarao City, Philippines. Asia Pacific Journal of Multidisciplinary Research, 5,(1), 47-54

Zhang, X. F. \& Ng, H. M. (2011). "A Case Study of Teacher Appraisal in Shanghai, China: In Relation to Teacher Professional Development. Asia Pacific Educational Review, 12, 569-580, DOI 10.1007/s 12564-011-9159-8. 